\title{
PENGEMBANGAN APLIKASI KNOWLEDGE MANAGEMENT SYSTEM ONLINE UNTUK BERBAGI PENGETAHUAN ANTARA ALUMNI DENGAN PROGRAM STUDI
}

\author{
Meyvie Yolanda Lopis ${ }^{1}$, Ade Iriani ${ }^{2}$, Yari Dwikurnaningsih ${ }^{3}$ \\ ${ }^{123}$ Magister Manajemen Pendidikan, Universitas Kristen Satya Wacana \\ e-mail: 942016017@student.uksw.edu
}

\begin{abstract}
Abstrak
Tujuan Penelitian ini adalah mengembangkan Aplikasi Knowledge Management System Online untuk memfasilitasi berbagi pengetahuan antara alumni dengan alumni, dan alumni dengan Program Studi. Metode Penelitian menggunakan Research and Development menurut Borg and Gall yang sudah dimodifikasi oleh Sukmadinata (2006). Prosedur Pengembangannya meliputi: (1) studi pendahuluan yang terdiri dari studi pustaka, studi lapangan, penyusunan draf produk; (2) pengembangan yang terdiri dari validasi ahli dan revisi produk; (3) pengujian melalui uji coba terbatas dan revisi untuk memperoleh produk akhir. Validasi ahli dilakukan oleh ahli Teknologi Informasi dan Komunikasi serta ahli Manajemen. Ujicoba terbatas dilakukan pada staff administrasi dan alumni Program Studi Magister Manajemen Pendidikan Fakultas Keguruan dan IImu Pendidikan Universitas Kristen Satya Wacana. Teknik Pengumpulan data Menggunakan angket. Data dianalisis menggunakan teknik analisis deskriptif kuantitatif. Hasil penelitian berupa aplikasi Knowledge Management System Online dan Panduan Penggunaan Aplikasi yang sudah divalidasi oleh ahli dan ujicobakan dengan hasil sangat layak.
\end{abstract}

Kata kunci : Berbagi Pengetahuan, Knowledge Managemet, R\&D, Aplikasi Pengembangan

\begin{abstract}
The aim of this research is to develop the online Knowledge Management System Application to facilitate the sharing knowledge among the alumni and between the alumni, as well as between the alumni and the study programme. Research and Development method is used in this research which has been modified by Sukmadinata (2006). The development procedure are: (1) Preliminary study which include literature review, observation, product drafting; (2) Development which consist of expert validation and product revision; (3) Testing which consist of trial in limited area, and revision to formulate the final product. Validation was done by the one who is an expert both in Communication and Information Technology and Education Management. Questionnaire was used to collect data and the data was analyzed by descriptive quantitative technique. The application Knowledge Management System Online and
\end{abstract}

Keywords : Knowledge Sharing, Knowledge Management, R\&D, Application Development 


\section{PENDAHULUAN}

Pendidikan Teknologi Informasi (TI) telah menjadi salah satu kebutuhan dalam lingkungan bisnis. Peranan teknologi sebagai alat bantu dalam menjalankan sebuah proses bisnis, tidak lagi bisa dipisahkan. Khususnya dilingkungan perguruan tinggi (PT), penerapan TI dapat dimanfaatkan dalam keberlanjutan manajemen PT. dalam lingkup manajemen PT, (Bancin, 2006) berpendapat bahwa manajemen PT tidak hanya sebatas aspek pengajaran dan administrasi kesiswaan; dengan kata lain bahwa manajemen PT tidak hanya mencakup pengelolaan dalam lingkup internal saja, namun lingkup external juga menjadi salah satu bagian terpenting dalam pelaksanaan manajemen sebuah PT, salah satunya adalah pengelolaan alumni. Keuntungan dari keterlibatan alumni dalam lingkungan PT adalah sebagai pintu gerbang pengetahuan yang bersumber dari external PT. Salah satu pengetahuan yang bersumber dari alumni adalah pengetahuan terkait kebutuhan industri terhadap tenaga kerja. Dengan demikian penting untuk dimanage setiap pengetahuan yang dibagikan.

Aplikasi Secara istilah pengertian aplikasi adalah suatu program yang siap untuk digunakan yang dibuat untuk melaksanankan suatu fungsi bagi pengguna jasa aplikasi serta penggunaan aplikasi lain yang dapat digunakan oleh suatu sasaran yang akan dituju. Menurut kamus computer eksekutif, aplikasi mempunyai arti yaitu pemecahan masalah yang menggunakan salah satu tehnik pemrosesan data aplikasi yang biasanya berpacu pada sebuah komputansi yang diinginkan atau diharapkan maupun pemrosesan data yang di harapkan. Pengertian aplikasi menurut Kamus Besar Bahasa Indonesia, "Aplikasi adalah penerapan dari rancang sistem untuk mengolah data yang menggunakan aturan atau ketentuan bahasa pemrograman tertentu" (Juansyah, 2015).

Pelaksanaan Berbagi Pengetahuan terdiri dari kegiatan yang dipandu untuk pengembangan sebuah PT, mendorong budaya akuisisi pengetahuan, dan penggunaan pengetahuan tersebut (Pinto,2014). Dalam prakteknya berbagi pengetahuan mengarah pada peningkatan eksponensial dapat menguntungkan berbagai proses dan layanan kunci dalam lembaga pendidikan tinggi. Pengetahuan yang dimiliki oleh PT dapat dengan mudah disampaikan kepada alumni, sebaliknya pengetahuan yang dimiliki oleh alumni dapat dengan mudah diberikan kepada PT. Hubungan timbal balik tersebut merupakan kondisi dimana Berbagi Pengetahuan memiliki peran penting dalam pelaksanaan manajemen PT tidak hanya mencakup kepengurusan administrasi dan lain-lain, namun membangun hubungan dengan alumni menjadi faktor penting dalam mengembangkan kualitas akademiknya, tidak terkecuali di Program Studi (PRODI) Magister Manajemen Pendidikan (MMP) Fakultas Keguruan dan IImu Pendidikan (FKIP) Universitas Kristen Satya Wacana (UKSW).

Kondisi yang terjadi di PRODI MMP FKIP UKSW, hubungan antara alumni dengan PRODI MMP FKIP UKSW terjadi melalui pertemuan tatap muka dan lewat jejaring sosial. Hal ini disebabkan oleh banyak faktor baik itu jarak dan waktu antara PRODI MMP FKIP UKSW dengan alumni, kurangnya infrastruktur yang memadai dan faktor-faktor lainnya. Rattanamethawong memberikan gambaran bahwa hubungan Perguruan tinggi dan alumni diwarnai dengan beberapa hal, antara lain: 1) alumni tidak merasa bahwa universitas telah memberi mereka informasi dan manfaat yang berguna bagi mereka; 2) alumni dilacak hanya untuk mencari sumbangan dana ke universitas; 3) universitas cenderung memperlakukan anggota alumni yang sukses dan lebih tua lebih baik dari yang baru dan yang kurang sukses; 4) hubungan antara dosen, mahasiswa yang ada, dan alumni sangat lemah karena tidak ada keterikatan dengan universitas setelah lulus (Rattanamethawong, Sinthupinyo, \& Chandrachai, 2017). Berlandaskan pada kondisi tersebut, maka membangun relasi antara Program Studi dengan alumni dan Alumni dengan alumni menjadi sangat penting.

Mengacu pada kondisi yang telah diuraikan, maka disadari bahwa penerapan Berbagi Pengetahuan dilingkungan PT khususnya Prodi MMP FKIP UKSW sangatlah penting. Dengan demikian melalui penelitian ini yang bertujuan untuk membangun sebuah desain sistem yang berfokus pada hubungan antara Program Studi dengan Alumni dan Alumni dengan Alumni.

Penelitian yang berjudul "Knowledge Management in Higher Education Institutions: A framework to improve collaboration". Penelitian tersebut bertujuan untuk menyajikan framework yang berfungsi untuk meningkatkan Berbagi Pengetahuan dan kolaborasi di Institusi Pendidikan Tinggi. Penelitian ini membahas konsep manajemen pengetahuan di PT, menyajikan sistematisasi praktik dan alat pengetahuan untuk menghubungkan 
orang (siswa, guru, peneliti, staf sekretariat, entitas eksternal) dan mempromosikan Berbagi Pengetahuan di beberapa proses dan layanan utama dalam sebuah PT, seperti: proses penelitian, proses belajar, layanan siswa dan alumni, layanan dan proses administrasi, dan perencanaan dan manajemen strategis. Framework yang dimaksudkan dalam penelitian tersebut bertujuan untuk memperbaiki praktik dan proses pengetahuan yang memfasilitasi lingkungan dan budaya kolaborasi, berbagi dan penemuan pengetahuan yang harus menjadi ciri PT (Pinto, 2014).

Penelitian lainnya yang berjudul "Designing Knowledge Management Model for Curriculum Development Process: A Case Study in Bina Nusantara University". Penelitian ini mengusulkan model Knowledge Management untuk pengembangan kurikulum. Survei dilakukan di Universitas Bina Nusantara, dengan mewawancarai staff yang terlibat dalam proses pengembangan kurikulum untuk memahami prosesnya. Studi literatur diterapkan untuk mengembangkan model yang sesuai dengan integrasi antara sistem manajemen pengetahuan sebagai sumber pengetahuan ke dalam Sistem Manajemen Pembelajaran di Universitas Bina Nusantara sebagai studi kasus. Sebagai hasilnya, model Knowledge Management ini mendukung beberapa pemangku kepentingan seperti program Studi, Subyek Content Coordinator, Dosen, Mahasiswa, dan Alumni \& Mitra untuk memperbaiki proses pengembangan kurikulum yang ada (Tjong \& Adi, 2016).

Sedangkan penelitian yang berjudul "The Knowledge Management in Higher Education in Chiang Mai:A Comparative Review", berfokus pada perbandingan manajemen pengetahuan dalam pendidikan tinggi. Studi ini menemukan bahwa, pemanfaatan pengetahuan di lembaga pemerintah dianggap pada tingkat moderat sementara di lembaga swasta berada pada tingkat yang tinggi. Dampaknya adalah Berbagi Pengetahuan dalam lembaga pemerintah dan swasta tidak begitu maksimal. Disisi lain, hubungan antara budaya organisasi dan proses manajemen pengetahuan lembaga pemerintah dan swasta pada tingkat sedang. Akibatnya, anggota fakultas harus berkonsentrasi pada visi, misi dan strategi manajemen pengetahuan kelembagaan jika mereka ingin mencapai manfaat dari lembaga (Songsangyos, 2012).

Mengacu pada penelitian-penelitian terdahulu yang ada, pada penelitian ini akan lebih berfokus pada pengembangan sistem
Berbagi Pengetahuan di lingkungan PRODI MMP UKSW dengan menggunakan model SECI dalam pelaksanaannya.

Dalam konteks tersebut, secara umum PT memiliki tanggung jawab untuk melaksanakan fungsi layanan Tri Dharma, yaitu pendidikan dan pengajaran, penelitian, dan pengabdian kepada masyarakat. PT di Indonesia memiliki kemiripan karena di dasarkan pada peraturan pemerintah. Namun dalam pelaksanaannya, manajemen PT tidak hanya sebatas manajemen dalam lingkup internal, namun terdapat pula lingkungan external yang berperan dalam manajemen sebuah PT (Bancin, 2006; Tjong \& Adi, 2016). Adapun lingkungan external yang dimaksud adalah: orangtua mahasiswa, alumni dan industri.

Secara garis besar, Torrington and Weightman (Dennison et al., 1992) menekankan bahwa manajemen pendidikan ditandai oleh keragaman dan permintaan. Pemahaman tersebut dapat diartikan bahwa adanya verifikasi pihak-pihak yang terlibat didalam proses manajerial, termasuk didalamnya adalah menjaga hubungan yang produktif dengan alumni. Prioritas utama dari manajemen pendidikan tinggi adalah integrasi kelembagaan yang strategi dan berurusan dengan keragaman realita sehari-hari yang menjembatani semua aspek pengajaran universitas dan administrasi kesiswaan (Berglund, 1998). Dengan demikian, ruang lingkup manajemen pendidikan tinggi tidak dapat dipisahkan dari peranan para alumni. (Rattanamethawong et al., 2017) mengembangkan sebuah model untuk memprediksi perilaku mendukung siswa dan alumni dari ketika alumni masih menjadi mahasiswa atau baru memasuki universitas sampai pada masa kelulusannya. Dalam pelaksanaannya, model tersebut menggunakan metode clustering atau pengelompokkan alumni memberikan kejelasan bahwa kebutuhan alumni sangat berbeda-beda. Tidak hanya para alumni, PT pun memiliki kebutuhan akan informasi yang bersumber dari external PT. Pemahaman tersebut juga ditekankan (Tjong \& Adi, 2016) bahwa alumni dapat berperan dalam proses mereview kurikulum.

Berbagi Pengetahuan merupakan salah satu bagian komponen dari Knowledge Management (Pinto, 2014). Menurut para ahli Knowledge Management adalah sebuah proses dimana organisasi telah merumuskan cara dalam upaya mengenali dan mengarsipkan aset pengetahuan di dalam organisasi, sebagai contoh pengetahuan yang 
berasal dari karyawan berbagai departemen atau fakultas dan dalam beberapa kasus, bahkan dari organisasi lain yang memiliki ruang lingkup yang sama (Laal, 2011). Berbagi Pengetahuan secara umum dapat diartikan sebagai sebuah proses yang memungkinkan organisasi menciptakan nilai dari aset intelektual dan aset lainnya yang berbasis pada pengetahuan. Hal ini dilakukan melalui kondisi yang diketahui oleh individu serta mitra organisasi yang saling berbagi informasinya di antar mereka dalam upaya mengembangkan best practices. Berbagi Pengetahuan didukung dan difasilitasi oleh Teknologi Informasi, namun teknologi informasi bukanlah Manajemen Pengetahuan. tidak semua informasi berguna dan tidak semua informasi tidak berguna. Tergantung pada masingmasing organisasi untuk menentukan informasi apa yang tergolong sebagai aset intelektual dan aset lainnya yang berbasis pengetahuan. Aset-aset tersebut dapat dikelompokkan sebagai pengetahuan Eksplisit atau Implisit (Pengetahuan tacit)

Keberhasilan inisiatif manajemen pengetahuan tergantung pada Berbagi Pengetahuan (Jafari Navimipour \& Charband, 2016; S. Wang \& Noe, 2010). Berbagi Pengetahuan antara alumni dan PT memungkinkan PT untuk mengeksploitasi dan memanfaatkan sumber daya berbasis pengetahuan tanpa ada batasan dan sarana dasar di mana pertukaran pengetahuan memiliki kontribusi dalam pemanfaatan pengetahuan dan inovasi yang merupakan salah satu keunggulan dari sebuah organisasi (S. Wang \& Noe, 2010; Z. Wang \& Wang, 2012). Berbagi pengetahuan ialah fondasi sosialisasi, secara eksplisit membentuk kombinasi yang dapat di gunakan dalam sebuah organisasi tertentu, dan secara Praktik Berbagi Pengetahuan tampak lebih umum di dalam dunia nyata karena pengetahuan yang eksplisit dapat dengan mudah ditangkap, dikodifikasikan dan ditransmisikan (Z. Wang \& Wang, 2012).

Pentingnya Berbagi Pengetahuan dalam sebuah organisasi jelas dipandang sebagai sebuah kelebihan dan menjadi sebuah sumber daya. Dilingkungan PT didasarkan atas beberapa alasan penting, antara lain: 1)Sebagai dasar dalam pengambilan keputusan bagi para petinggi di PT; 2) Sumber informasi dalam pengembangan kurikulum; 3) Mempersiapkan tenaga kerja yang sesuai dengan kebutuhan dunia kerja; 4) Sebagai sarana untuk menjaring para mahasiswa baru; 5) Sebagai sarana untuk membagi informasi kepada para alumni.
Pemimpin sebuah organisasi selalu mencari celah dalam merancang sistem manajemen pengetahuan dan menjalankannya di dalam organisasi mereka (Yaghoubi \& Maleki, 2012) . Celah tersebut harus didasarkan atas kebutuhan akan pengetahuan yang dimiliki oleh individu/perseorangan dalam hal ini alumni. Pengetahuan yang dimiliki masing-masing alumni, sangatlah bervariasi, dan tidak menutup kemungkinan bahwa pengetahuan-pengetahuan tersebut tidak memberikan manfaat bagi PT. maka dari hal itu penting untuk dilakukan penyaringan, pemisahan dan pengelompokan pengetahuan yang didapat, yang mana harus didasarkan atas kebutuhan pengetahuan dalam lingkup PT, karena tidak semua informasi akan bermanfaat bagi PT. Sebagai contoh, pada saat PT ingin mengembangkan kurikulum yang disesuaikan dengan industri, PT harus benarbenar tahu tentang spesifikasi tenaga kerja yang dibutuhkan oleh industri. Maka pada kondisi tersebut, salah satu peranan Berbagi Pengetahuan adalah untuk memfasilitasi dan mengelompokkan pengetahuan yang didapat dari para alumni yang memberikan masukan ataupun tanggapan yang berhubungan dengan kurikulum dan kebutuhan industri, pengetahuan diluar itu haruslah dikelompokkan dengan kelompok yang lain.

Nonaka berpendapat bahwa pengetahuan merupakan suatu hal yang dinamis dan dapat berubah bentuk antara Tacit dan Explicit. Mereka kemudian mengusulkan suatu model dalam proses penciptaan pengetahuan, yang kemudian memungkinan organisasi untuk mengelola proses tersebut secara efektif. Mereka mengajukan empat langkah penciptaan pengetahuan disebut model SECI atau Socialization, Externalization, Combination, dan Internalization (Modinou, Liaropoulos, Kaitelidou, Kioulafas, \& Theodoraki, 2011).

\begin{tabular}{|l|l|c|}
\hline From $/ T_{0}$ & \multicolumn{1}{|c|}{ Tacit } & \multicolumn{1}{c|}{ Explicit } \\
\hline Tacit & \multicolumn{1}{|c|}{$\begin{array}{c}\text { Socialisation } \\
\text { Creates sympathised knowledge } \\
\text { through the sharing of experiences, } \\
\text { and the development of mental } \\
\text { models and technical skills. } \\
\text { Language unnecessary. }\end{array}$} & $\begin{array}{l}\text { Extisation } \\
\text { Creates conceptual knowledge through } \\
\text { knowledge articulation using language. } \\
\text { Dialogue and collective reflection needed. }\end{array}$ \\
\hline Explicit & \multicolumn{1}{|c|}{$\begin{array}{c}\text { Internalisation } \\
\text { Creates operational } \text { knowledge } \\
\text { through learning by doing. Explicit } \\
\text { knowledge like manuals or verbal } \\
\text { stories helpful. }\end{array}$} & $\begin{array}{l}\text { Combination } \\
\text { Creates systemic knowledge through the } \\
\text { systeming of ideas. May involve many } \\
\text { media, and can lead to new knowledge } \\
\text { through adding, combining \& } \\
\text { categorising. }\end{array}$ \\
\hline
\end{tabular}

Gambar 1.Model Seci (Modinou et al., 2011). 
a. Socialization: membagikan Pengetahuan dari satu individu ke individu lainnya dalam bentuk tacit Pengetahuan. Disebutkan bahwa Socialization muncul dari aktivitas "berbagi dan menciptakan pengetahuan tacit melalui pengalaman langsung".

b. Externalization: TransformasPengetahuan dari bentuk Tacit ke bentuk Explicit. Dengan externalization, pengetahuan tacit yang ada dalam diri individu di keluarkan dan diformulasikan ke dalam media lain yang dapat dengan mudah dipelajari oleh individu lain.

c. Combination: Mengorganisasi kumpulan Explicit Pengetahuan ke dalam satu bentuk media yang lebis sistematis, melalui proses penambahan Pengetahuan baru, kombinasi dan kategorisasi pengetahuan yang telah terkumpul.

d. Internalization: Tranformasi pengetahuan dari bentuk Explicit ke bentuk Tacit. Contohnya dengan proses belajar yang kemudian diikuti dengan 'learning by doing' yang lambat laun membentuk pengetahuan baru dalam diri individu.

\section{METODE}

Jenis penelitian yang digunakan adalah Penelitian dan pengembangan / Research and Development (R\&D). Berbagai tipe model pengembangan produk manajemen pendidikan pada umumnya menggunakan pendekatan linier, dimana proses pengembangan berlangsung tahap demi tahap secara kausal. Dalam kenyataannya proses pengembangan sesuatu produk akan selalu memperhatikan berbagai elemen pendukung maupun unsur-unsurnya sehingga akan terjadi proses yang rekursif (Rosana, 2008). Borg \& Gall (2007) mengatakan ada 10 tahap penelitian dan pengembangan yang di lakukan untuk menghasilkan produk yang di maksud yaitu (Gall, Gall, \& Borg, 2003):

1. Research and information collecting dalam langkah ini pengumpulan studi pustaka dan studi lapangan penelitian pengembangan. Dalam tahapn ini dilakukan wawancara dengan pihak terkait, dalam hal ini pihak MMP UKSW dan alumni.

2. Planning dalam langkah penelitian ini merencanakan penelitian berdasarkan tahap 1. Dalam tahapan ini, dilakukan rancangan sistem yang disesuaikan dengan model SECI.

3. Develop preliminary form of product yaitu perencanaan produk awal, Persiapaan komponen pendukung ketercapaain hasil peneltian.
4. Preliminary Field Testing yaitu pelaksanaan uji coba awal dalam skala kecil.

5. Main Product Revision yaitu tahap revisi dari uji coba awal dan menjadi patokan untuk pelaksanaan uji coba yang lebih besar, tahap ini dapat di lakukan sampai pencapaain hasil produk yang layak untuk di uji coba para ahli.

6. Main Field Testing merupakan Pengujian utama dalam penelitian pengembangan

7. Operational Product Revision yaitu melakukan Revisi produk terhadap hasil uji coba utama sehingga produk yang dihasilkan sesuai dengan tujuan pembuatan produk dan dapat divalidasi.

8. Operational field Testing yaitu langkah uji validasi terhadap produk yang telah dikembangkan. Langkah ini dilakukan validasi para ahli yakni orang-orang yang berkompeten dalam bidang ilmu yang bersangkutan.

9. Final Product Revision yaitu perbaikan akhir terhadap produk yang telah di kembangkan guna hasil produk akhir;

10.Dissemination and implementation yaitu produk yang telah di kembangkan dapat di publikasi secara luas.

Penelitian pengembangan berbagi pengetahuan dilakukan pada lingkungan Prodi MMP FKIP UKSW yang menyesuaikan dengan model pengembangan yang dilaksanakan dengan penyederahanaan langkah penelitian dan pengembangan berdasarkan standar model pengembangan Borg \& Gall dimodifikasi oleh Sukmadinata dkk (2009) secara dasarnya ada 3 tahap, yaitu: (1) studi pendahuluan, (2) pengembangan model, dan (3) pengujian

\section{HASIL DAN PEMBAHASAN}

Mengacu pada hasil wawancara yang dilakukan terkait proses berbagi pengetahuan antara Prodi dengan alumni, dan alumni dengan alumni, ditemukan permasalahan yang terjadi selama ini dilingkungan Prodi, khususnya terkait berbagi pengetahuan antara pihak prodi dengan alumni. Kondisi-kondisi tersebut sebagai berikut:

1) Proses Berbagi pengetahuan dengan alumni melalui kegiatan temu alumni. Kegiatan tersebut tidak terprogram. Kelebihan dari kegiatan ini adalah Prodi dengan alumni dapat bertemu secara langsung dan saling berbagi informasi yang ada.

2) Membagikan pengetahuan melalui grup aplikasi whatsapp. Dalam kondisi tersebut, 
terdapat informasi yang bersifat informative. Kelebihan dari aktifitas ini adalah alumni mampu secara langsung dapat menyampaikan setiap pengetahuan yang dimilikinya.

3) Membagikan pengetahuan melalui kegiatan-kegiatan yang tidak terencana. $\mathrm{Hal}$ ini yang dimaksudkan adalah melalui kegiatan seminar, rapat, dll. Kelebihan dari kondisi ini adalah adanya proses tatap muka secara langsung antara prodi dan alumni.

Mengacu pada kondisi yang telah diuraikan, maka dapat diartikan bahwa tidak adanya rekapan terhadap setiap pengetahuan yang diterima atau pun yang dibagikan. Dengan demikian, hal tersebut menjadi dasar dalam pengembangan sistem.

\section{A. Desain.}

Terdapat beberapa bagian dalam desain yang dibangun antara lain: bagian data alumni, artikel dan FAQ (Frequently asked questions). Bagian data alumni adalah bagian yang berfungsi untuk melakukan pencatatan data alumni. Ruang lingkup data alumni yang digunakan dalam pelaksanaan rekap yakni: email, nama, jenis kelamin, nomer telepon (hp), alamat, tanggal lulus, lama studi, nim semasa kuliah, jenjang pendidikan, program studi, tanggal bekerja, nama pekerjaan, status kepegawaian, nama instansi tempat bekerja dan alamat instansi tempat bekerja. Sedangkan bagian artikel mencakup judul dan konten artikel, sama halnya dengan FAQ. Namun yang membedakan antara artikel dan FAQ adalah artikel berisikan informasiinformasi terkait testimoni, info lowongan pekerjaan, dan informasi-informasi lainnya. Sedangkan FAQ berisikan daftar pertanyaanpertanyaan yang dapat disampaikan oleh para pengguna dalam hal ini admin dan alumni.

Untuk mengakses keseluruhan fungsi yang ada didalam sistem maka masing-masing pengguna harus melakukan login terlebih dahulu. Proses login yang digunakan adalah dengan memanfaatkan google sign-in. ketentuan pengelompokan pengguna yang berlaku dalam sistem ini adalah, pengguna yang mengakses sistem ini tanpa menggunkan login adalah pengguna public, sedangkan pengguna yang melakukan login adalah pengguna alumni dan admin. Pembagian antara admin dan alumni mlalui acuan dari penentuan akun yang diyakini adalah pegawai dalam lingkungan Prodi MMP UKSW, sedangkan diluar daripada itu, adalah alumni.

Role akses dari public adalah read only, dimana setiap user yang menjadi kelompok public hanya dapat mebaca artikel dan FAQ, sedangkan bagian alumni, pengguna public hanya dapat melihat rekapan data alumni dalam bentuk grafik.

Role akses dari pengguna alumni adalah read, add dan delete. Hal ini dimaksudkan bahwa alumni dapat melihat artikel, menambahkan artikel dan menghapus artikel. Proses menghapus artikel didasarkan pada artikel yang dimuat oleh alumni terkait atau dapat diartikan bahwa artikel yang ditambahkan oleh alumni A hanya dapat dihapus oleh alumni $A$, tidak oleh alumni lainnya. Proses tersebut juga berlaku pada bagian FAQ dan komentar pada artikel dan FAQ. Sedangkan bagian alumni, pengguna public hanya dapat melihat rekapan data alumni dalam bentuk grafik.

Role akses admin adalah read, add dan delete. Hal ini dimaksudkan bahwa alumni dapat melihat artikel, menambahkan artikel dan menghapus artikel. Berbeda dengan alumni, admin dapat menghapus setiap artikel, maupun FAQ yang ada tanpa ada batasan. Sedangkan bagian alumni, pengguna admin dapat menambahkan data alumni dan menghapus data alumni. Sedangkan untuk proses perubahan data alumni, sepenuhnya adalah ytanggungjawab alumni. Dikarenakan terdapat beberapa data spesifik yang hanya bisa dilengkapi oleh alumni bersangkutan seperti data pekerjaan.

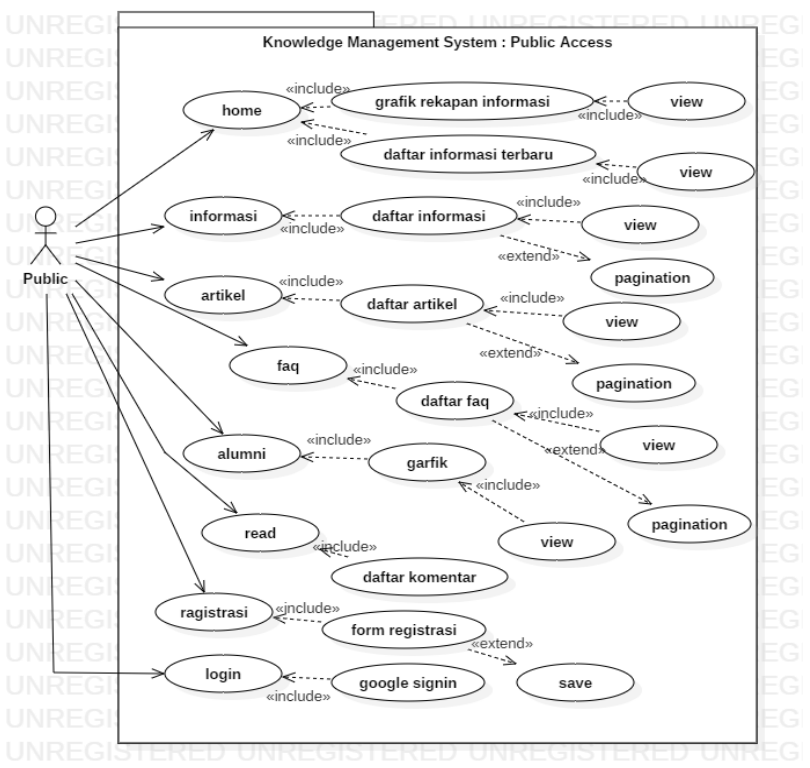

Gambar 2.Pengguna public 


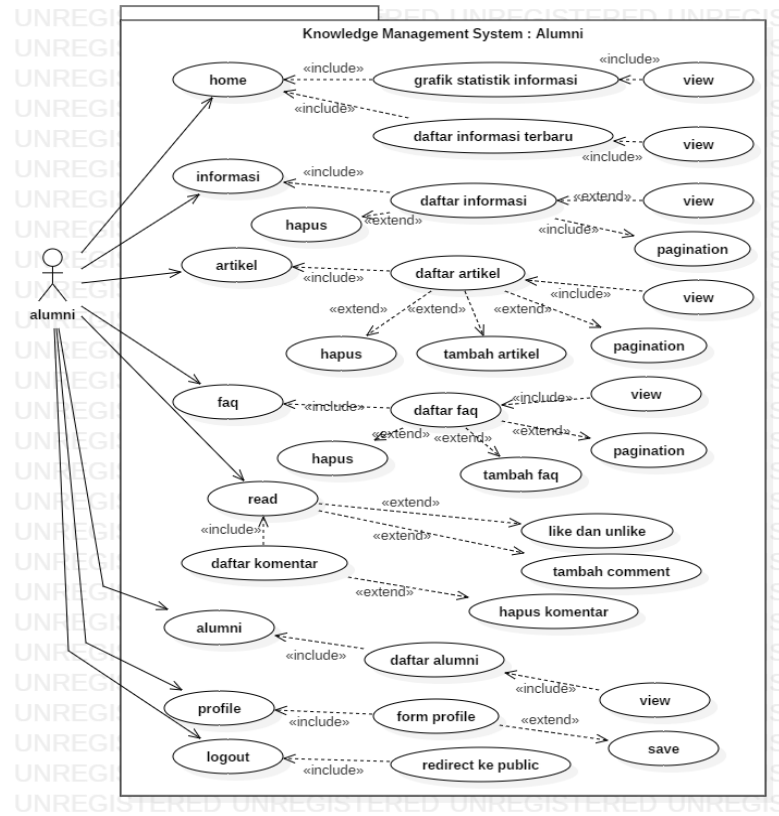

Gambar 3.Akses Alumni

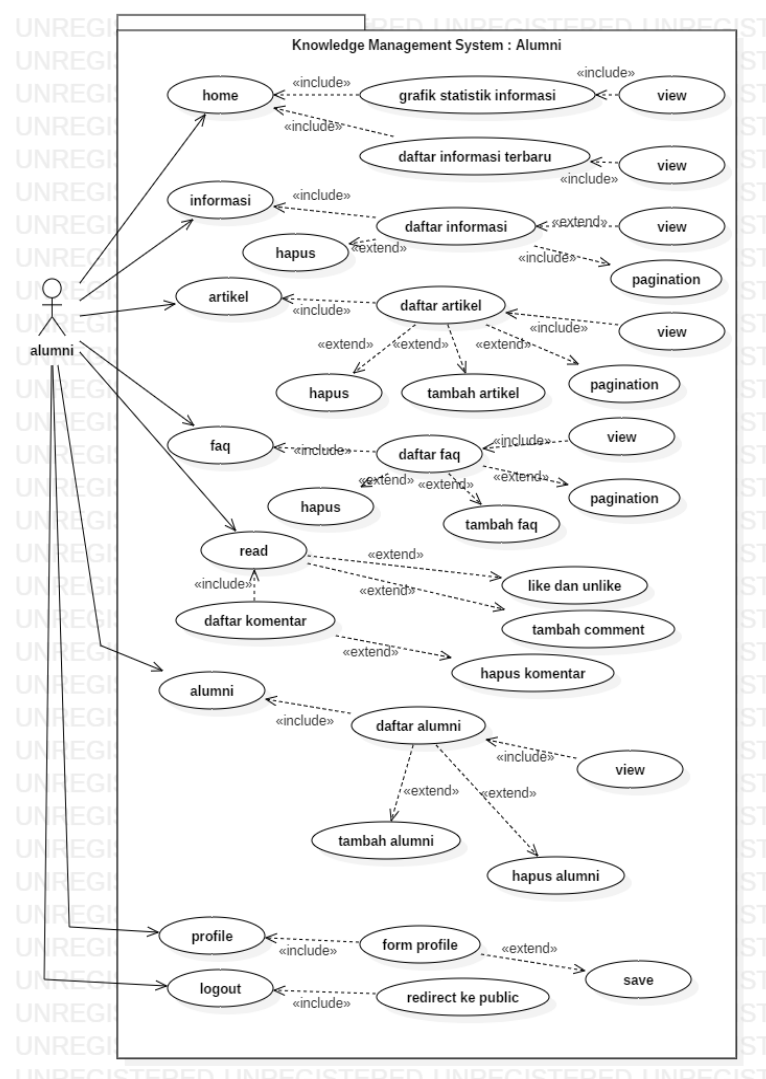

\section{Gambar 4}

Berdasarkan hasil desain sistem yang ada maka terdapat alur kerja sistem yang diuraikan sebagai berikut:

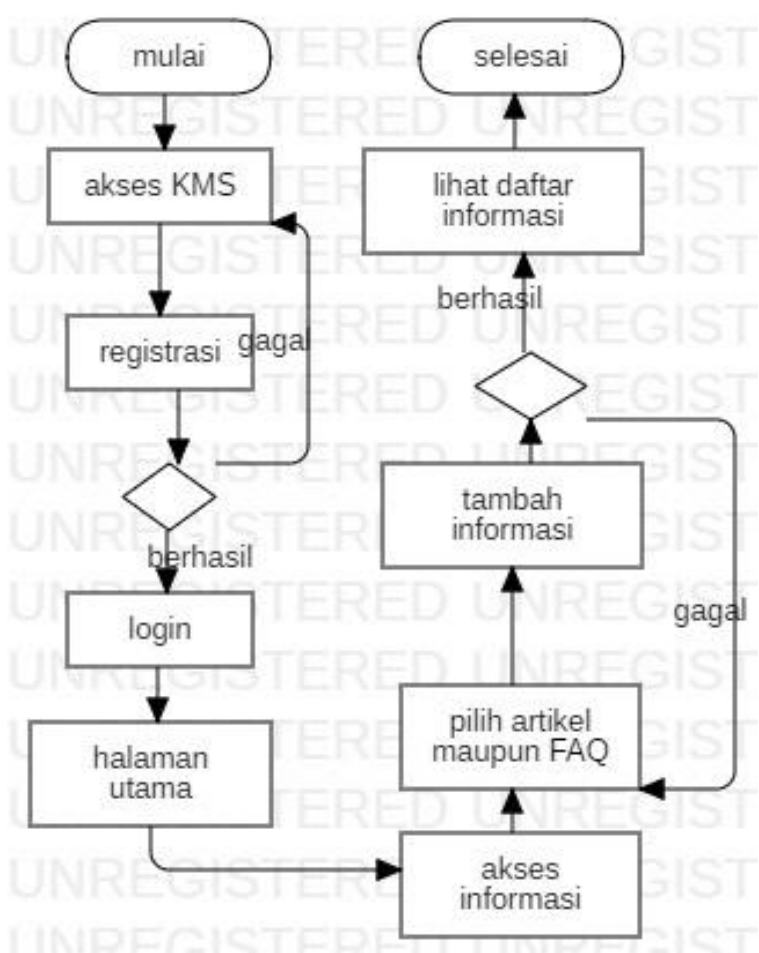

Gambar 5.Diagram Alur Akses informasi KMS berdasarkan Alumni.

Pengguna alumni merupakan salah satu actor atau pengguna yang dapat menggunakan KMS. Pemberian hak akses kepada alumni dapat melalui prosedur yang telah ditetapkan (gambar 5). Adapun alur akses yang ada dapat diuraikan sebagai berikut: seorang alumni harus melakukan proses registrasi sebelum mengakses ingormasi yang ada; setelah alumni melakukan registrasi, maka alumni yang bersangkutan dapat melakukan login terlebih dahulu; setelah proses login berhasil dilakukan, maka alumni tersebut dapat menambahkan dan melihat daftar informasi yang ada. 


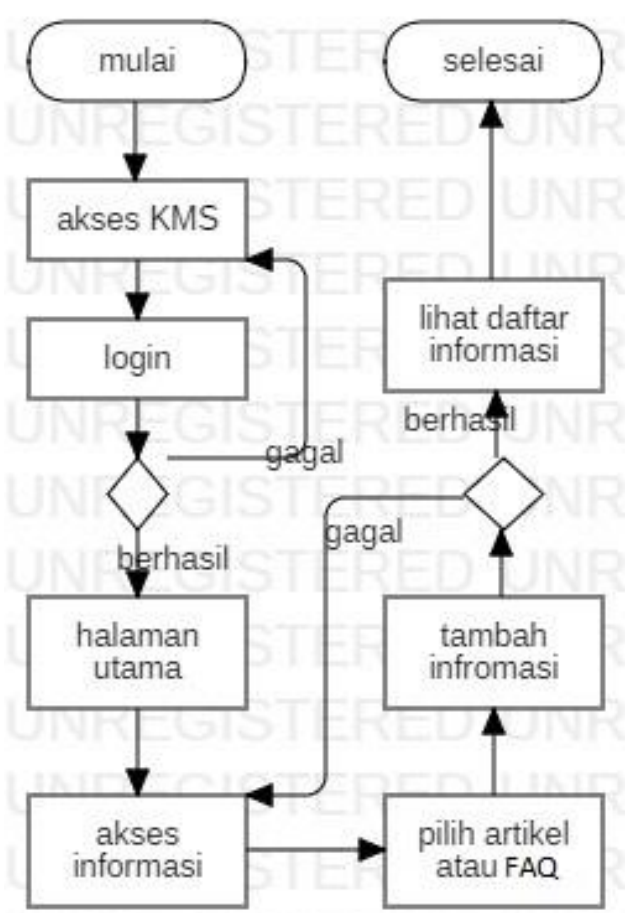

Gambar 6.Diagram Alur Akses informasi KMS berdasarkan Admin

Berbeda dengan alumni, pemberian hak akses kepada admin dapat melalui prosedur yang telah ditetapkan. Adapun alur akses yang ada dapat diuraikan sebagai berikut: seorang

admin harus melakukan proses login sebelum mengakses informasi yang ada; setelah proses login berhasil dilakukan, maka alumni tersebut dapat menambahkan dan melihat daftar informasi yang ada.

Salah satu hasil yang yang didapatkan dari penelitian ini adalah sebuah aplikasi KMS yang dapat digunakan oleh pengguna dalam hal ini alumni dan administrator dalam membagikan pengetahuan yang dimiliki. Hal ini dapat dilihat pada gambar 7, yang mana merupakan tampilan home aplikasi kms yang dibangun. Dalam tampilan tersebut, pengguna dapat melihat statistik rekapitulasi informasi yang dibagikan dan juga daftar informasi yang di bagikan.

Salah satu peranan dari KMS yang dibangun, disediakan fungsi untuk proses registrasi alumni ke-KMS (gambar 8). Hal ini bertujuan untuk mempermudah para alumni dalam dalam melakukan registrasi kedalam aplikasi KMS. Adapun terdapat item-item yang

digunakan dalam proses registrasi yang ada yakni email, nama lengkap, jenis kelamin,

nomer telepon, nim semasa kuliah dan tanggal lulus. Proses ini juga dimaksudkan agar mempermudah admin dalam melakukan tracking para alumni yang melakukan registrasi.

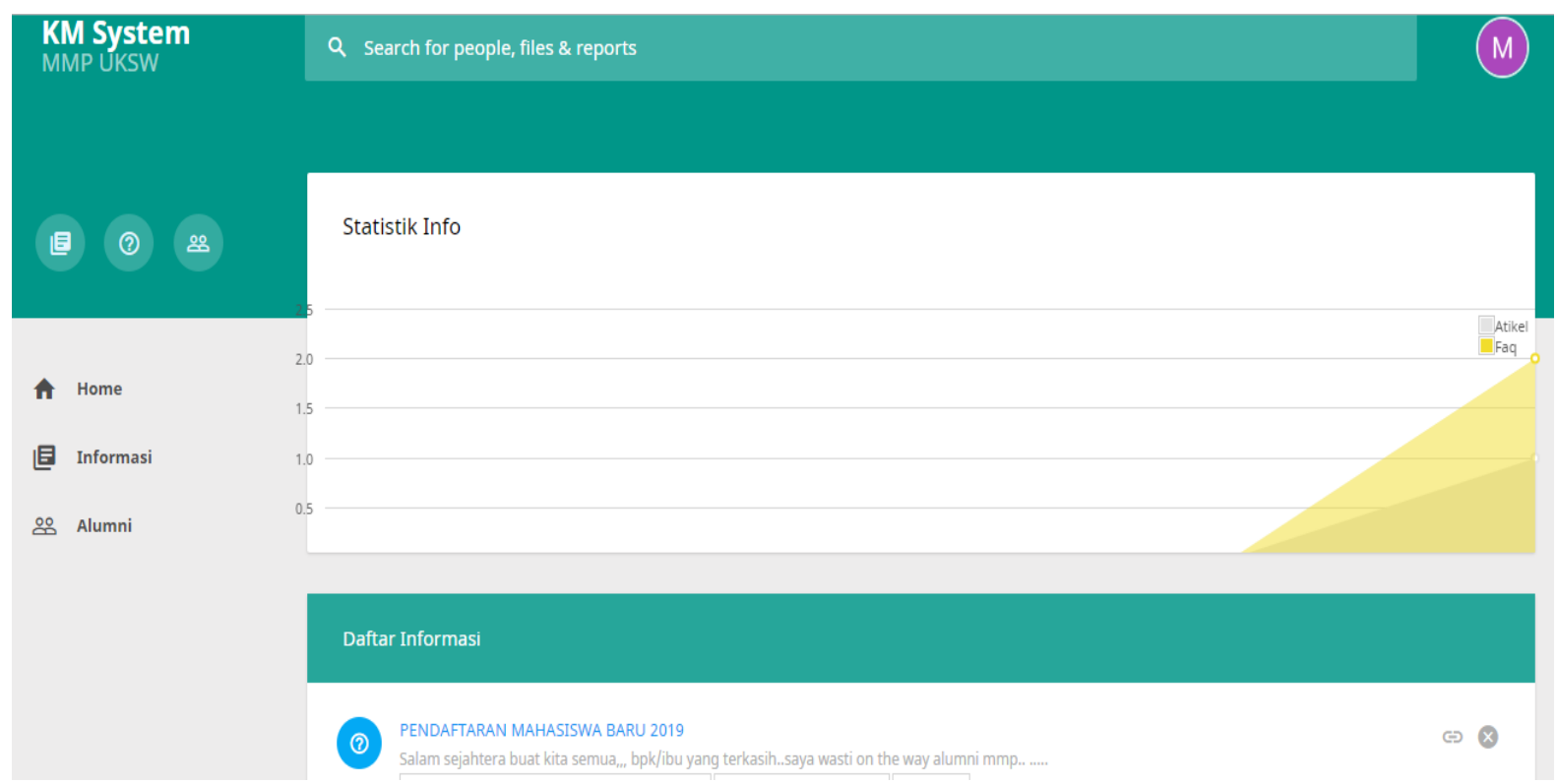

Gambar 7. Tampilan HOME KMS 


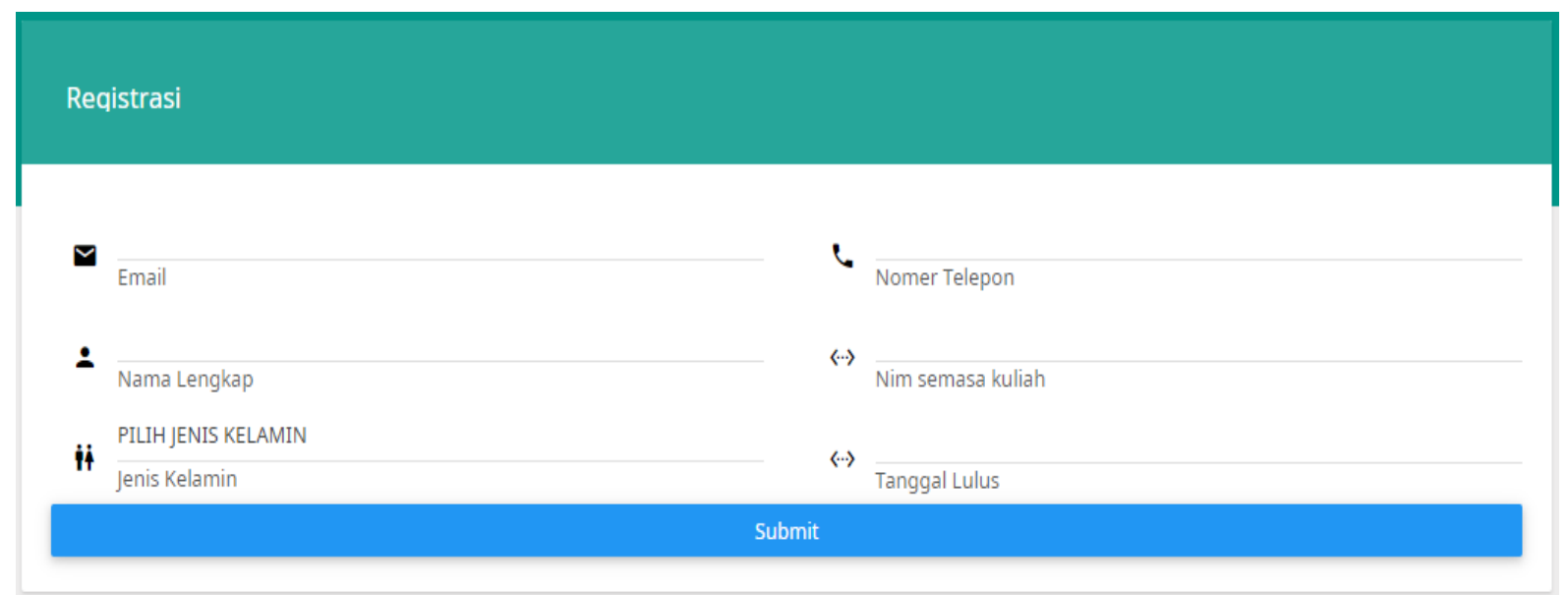

. Gambar 8. Tampilan Registrasi Alumni

Gambar 9. Tampilan Rekapan Data Alumni.

Pada prodi MMP FKIP UKSW saat ini proses berbagi pengetahuan terjadi pada pertemuan temu alumni yang tidak terprogram, berbagi pengetahuan dalam grup whatsapp, dan pertemuan yang tidak terencana antara alumni. Namun untuk berbagi pengetahuan ini dinilai belum adanya proses rekapan untuk setiap pengetahuan, belum adanya pengolahan. Menurut songayos dalam the knowledge Management in higher education in Chiang Mai: A comaparative review mengatakan Pengetahuan secara eksplisit dari anggota organisasi dapat dijelaskan dengan baik sehingga memiliki pemahaman yang sama dan mendapat pengetahuan diberikan dari anggota organisasi lainnya, Pemanfaatan pengetahuan tersebut didukung oleh infrastruktur yang mendukung teknologi informasi seperti Weblog, Wikis, dan forum populer lainnya yang memfasilitasi strategi kodifikasi pengetahuan, adanya konten kolaboratif dan adanya komunikasi sehingga tercapai nya visi, misi dan strategi manajemen pengetahuan institusi untuk mencapai manfaat bagi institusi. Pada Penelitian dan Pengembangan ini menghasilkan produk pengembangan aplikasi Knowledge Management System Online, dan untuk cara penggunaan aplikasi tersebut tersedia Panduan Penggunaan Aplikasi yang telah diuji dan divalidasi oleh ahli dengan skor kelayakan rata-rata 80.83 yang dikatakan sangat layak.

Berdasarkan hasil desain dan pengembangan sistem yang ada, ditentukan empat konversi pengetahuan yang digunakan yakni sosialisasi, eksternalisasi, kombinasi dan internalisasi (Tjong \& Adi, 2016). Hal ini dilakukan dengan tujuan yakni merangkum keseluruhan pengetahuan eksplisit yang kemudian akan diubah menjadi tacit.

Sosialisasi 
Dalam hal sosialisasi yakni konversi pengetahuan dengan cara berbagi informasi, pengalaman, testimonial dan menciptakan tacit. Hal ini dilakukan dalam beberapa cara yakni mengumpulkan informasi dari pihak terkait diantaranya alumni dan pihak MMP itu sendiri. pola tersebut dilakukan dengan cara berdiskusi melalui informasi yang di share disertai dengan tanggapan-tanggapan dari individu lainnya. Langkah lainnya yaitu berbagi testimoni yakni berbagi pengalaman terkait pengalaman belajar selama di MMP UKSW. Selanjutnya, Berbagi informasi terkait lulusan, pengembangan kurikulum, kebutuhan industri, dll. Langkah-langkah tersebut dapat menjadi alternative dalam proses koleksi pengetahuan baik itu untuk alumni maupun MMP.

Eksternalisasi.

Eksternalisasi yakni konversi tacit kedalam bentuk pengetahuan eksplisit dan proses artikulasi tacit menjadi pengetahuan eksplisit. Penciptaan pengetahuan tersebut dilakukan dengan cara menampung pengalaman dalam bentuk tulisan atau text. Proses tersebut mencakup: persiapan kajian mengenai kebutuhan akan pengetahuan. Sebagai contoh, pihak Program studi mempersiapkan artikel tekait akreditasi yang akan dipublikasi ke public; dari artikel atau FAQ yang di publikasikan, alumni akan mendapatkannya dan memberikan respon terkait informasi yang didapatkan.

Kombinasi.

Kombinasi adalah proses yang diakui sebagai eksplisit untuk konversi pengetahuan eksplisit dan konfigurasi sistem komputer yang sesuai kebutuhan Program studi yang ada melalui penyortiran, penambahan, penggabungan, dan pengkategorian pengetahuan secara eksplisit. Untuk meningkatkan efektivitas penggunaan sistem, transformasi dari eksplisit ke eksplisit akan dilakukan dengan kegiatan Ekstraksi, Transformasi, dan penambahan seperti: basis pengetahuan ke dalam sistem yang disediakan.

Internalisasi

Internalisasi merupakan konversi tacit dan proses mengintegrasikan pengetahuan eksplisit ke dalam pengetahuan tacit. Pengalaman dari sosialisasi, eksternalisasi, dan kombinasi yang diinternalisasi ke dalam pengetahuan tacit. Aktivitas untuk berubah dari pengetahuan eksplisit ke tacit adalah: Mendokumentasikan transfer pengetahuan pengetahuan eksplisit kepada pihak-pihak sebagai pelajaran dari pengalaman orang lain dan evaluasi terhadap pengetahuan yang berhasil dikumpulkan. Berdasarkan hasil konversi yang dilakukan, maka pengetahuan dan informasi diolah dan dishare. Pengolahan pengetahuan berkaitan dengan penciptaan pengetahuan eksplisit di mana produksi pengetahuan dibagi ke semua tingkat kegiatan dan berlaku untuk sistem KM melalui eksternalisasi dan kombinasi. Berbagi Pengetahuan berkaitan dengan penciptaan pengetahuan tacit di mana pengetahuan yang dihasilkan, dibagikan kepada semua pengguna melalui proses internalisasi dan sosialisasi.

\section{PENUTUP}

Proses pelaksanaan berbagi
pengetahuan di lingkungan di Prodi MMP FKIP
UKSW selama ini dilakukan secara tatap muka
melalui temu alumni yang tidak terprogram,
komunikasi melalui grup Whatsapp yang
belum dikelola dengan baik, Kelebihan dari
berbagi pengetahuan secara tatap muka dapat
leluasa dalam berkomunikasi secara langsung.
Adapun kelebihan berbagi pengetahuan
melalui whatsapp komunikasi dan berbagi
informasi dapat dilakukan secara cepat.
Kelemahan dari berbagi pengetahuan melalui
tatap muka dan whatsapp ialah tidak adanya
rekaman jejak yang tersimpan dengan baik
dan pembahasan kurang mengarah pada
topik-topik yang memiliki makna untuk
memperbaharui pengetahuannya. Berdasarkan hasil penelitian yang diuraikan maka kesimpulan yang dapat diambil sebagai berikut: Hasil Pengembangan ini berupa aplikasi Knowledge Management System Online yang sudah divalidasi oleh ahli IT dan ahli manajemen dengan hasil validasi dikatakan sangat layak untuk di ujicobakan. Produk ini juga sudah diujicobakan kepada staff administrasi dan alumni Program Studi Magister Manajemen Pendidikan FKIP UKSW dengan hasil sangat baik. Sistem KM yang dibangun dapat dikelola oleh pihak MMP untuk merekap pengetahuan yang bersumber dari alumni demi kepentingan Prodi. Dengan demikian, pihak Prodi dapat dengan mudah membagikan pengetahuan kepada para alumi secara efektif dan efisien. Proses berbagi pengetahuan yang digunakan tidak memiliki batasan dalam hal limitasi data. Hal ini dikarenakan, desain sistem yang dibangun dapat dimanfaatkan dalam membangun sebuah sistem dalam membantu melakukan rekapan data alumni yang relatif lebih mendetail, baik itu dari pengalaman selama berkuliah sampai pada dunia kerja yang alumni dilakoni oleh mereka. 


\section{DAFTAR PUSTAKA}

Bancin, A. (2006). Manajemen Perguruan Tinggi. Zenodo, $6(\mathrm{C}), \quad 1-6$. https://doi.org/10.5281/zenodo.1095811

Berglund, S. (1998). Consortium Governance Experiences of the Swedish LADOK Consortium. Higher Education Management, 10(1), 7-11. Retrieved from http://link.springer.com/chapter/10.1007/9 78-1-4899-6477-9 25

Dennison, W. F., Shenton, K., Leithwood, K. A., Rutherford, W., Van Der Vegt, R. Bailey, A. J., ... Tarrant, T. (1992). Managing external relations. Retrieved from

http://pubs.sciepub.com/education/1/6/7/i ndex.html

Gall, M. D., Gall, J. P., \& Borg, W. R. (2003). Educational Research. Educational Research: An Introduction.

Jafari Navimipour, N., \& Charband, Y. (2016). Pengetahuan sharing mechanisms and techniques in project teams: Literature review, classification, and current trends. Computers in Human Behavior, 62, 730742.

https://doi.org/10.1016/j.chb.2016.05.003

Juansyah, Andi. 2015. Pembangunan Aplikasi Child Tracker Berbasis Assisted - Global Positioning System (A-Gps) Dengan Platform Android . Jurnal Ilmiah Komputer dan Informatika (KOMPUTA) 1 Edisi. Volume. 1 Agustus 2015 ISSN : 20899033

Laal, M. (2011). Pengetahuan management in higher education. Procedia Computer Science, 3, 544-549. https://doi.org/10.1016/j.procs.2010.12.09 0

Modinou, O., Liaropoulos, L., Kaitelidou, D., Kioulafas, kyriakos, \& Theodoraki, E.-M. (2011). Management of Precancerous Lesions of the Uterine Cervix according to Demographic Data. ISRN Obstetrics and Gynecology (Vol. 2011). https://doi.org/10.5402/2011/301680

Pinto, M. (2014). Pengetahuan management in higher education institutions: A framework to improve collaboration. In 2014 9th Iberian Conference on Information
Systems and Technologies (CISTI) (Vol. ., pp. 1-4). IEEE. https://doi.org/10.1109/CISTI.2014.68768 76

Rattanamethawong, N., Sinthupinyo, S., \& Chandrachai, A. (2017). An innovation model of alumni relationship management: Alumni segmentation analysis. Kasetsart Journal of Social Sciences.

https://doi.org/10.1016/j.kjss.2017.02.002

Rosana, D. (2008). PERANAN RESEARCHAND DEVELOPMENT (R\&D) DAN STRUCTURAL EQUATIONMODEL (SEM) DALAM PENELITIAN PENGEMBANGAN KURIKULUM TINGKAT SATUAN PENDIDIKAN. Cakrawala Pendidikan, 2, 175-189.

Songsangyos, P. (2012). The Pengetahuan Management in Higher Education in Chiang Mai: A Comparative Review. Procedia - Social and Behavioral Sciences, 69(Iceepsy), 399-403. https://doi.org/10.1016/j.sbspro.2012.11.4 26

Tjong, Y., \& Adi, S. (2016). Designing Pengetahuan Management Model for Curriculum Development Process: A Case Study in Bina Nusantara University. International Conference on Information Management and Technology, (November), 17-22.

Wang, S., \& Noe, R. A. (2010). Pengetahuan sharing: A review and directions for future research. Human Resource Management Review, 20(2), 115-131. https://doi.org/10.1016/j.hrmr.2009.10.001

Wang, Z., \& Wang, N. (2012). Pengetahuan sharing, innovation and firm performance. Expert Systems with Applications, 39(10), 8899-8908

https://doi.org/10.1016/j.eswa.2012.02.01 7

Yaghoubi, N., \& Maleki, N. (2012). Critical Success Factors of Pengetahuan Management ( A Case Study: Zahedan Electric Distribution Company ). Journal of Basic and Applied Scientific Research, 2(12), 12024-12030. 